\title{
Distribusi Ukuran Spasial-Temporal dan Berdasarkan Tingkat Kematangan Gonad Rajungan (Portunus pelagicus Linnaeus 1758) di Teluk Lasongko, Buton Tengah, Sulawesi Tenggara
}

\author{
Abdul Hamid $^{1^{*}}$, Yusli Wardiatno ${ }^{2}$, Djamar T.F.Lumban Batu ${ }^{2}$, Etty Riani ${ }^{2}$ \\ 1) Jurusan Manajemen Sumberdaya Perairan, Fakultas Perikanan dan IImu Kelautan, Universitas \\ Halu Oleo, Kampus Hijau Bumi Tridharma Anduonohu Kendari 93232, Indonesia \\ ${ }^{2)}$ Departemen Manajemen Sumberdaya Perairan, Fakultas Perikanan dan IImu Kelautan, Institut Pertanian \\ Bogor, Gedung FPIK Lt. 3, Kampus IPB Darmaga - Bogor 16680, Indonesia \\ *Corresponding author: abdhamid_lamun@yahoo.com
}

Received 18 June 2016; Accepted 10 October 2016; Available online 29 November 2016

\begin{abstract}
The aim of the study was to reveal spatial-temporal distribution of the blue swimming crab (Portunus pelagicus Linnaeus 1758) in terms of size and gonad maturity stage of both male and female. Sampling of crab was conducted with a gill net from April 2013 until March 2014 in Lasongko Bay. Of the whole population the mean size of male was smaller than that of females. Spatially smaller crabs (juveniles and young ones) inhabited mostly inner side of the bay, while medium size crabs occurred in the middle part of the bay. Big crabs were mostly found in the outer side of the bay. In terms of time, big sise of male and female crabs were collected in period of October to November and September to March, respectively. Small size of male and female occurred in February to September and in April, respectively. Related to gonad maturity, the sizes of both sexes with mature stages were variable. Ovigerous female (OF) was presence widely in the bay, but the size of ovigerous females living in the shallow part of the bay was smaller than those living in the deeper part.
\end{abstract}

Keywords: blue swimming crab, size distribution, carapace width, spatial-temporal, gonad maturity

\section{Pendahuluan}

Indonesia merupakan negara dengan tingkat keanekaragaman biota laut yang tinggi, salah satunya adalah hewan krustasea. Hewan krustasea sebagai bahan target penelitian telah menjadi fokus peneliti dan koleganya selama beberapa tahun terakhir. Krustasea yang menjadi target penelitian lebih banyak pada krustasea laut seperti udang mantis (Harpiosquilla raphidea), rajungan (Portunus pelagicus), lobster, dan undur-undur laut (Ordo Hippoidea). Secara umum aspek yang diteliti pada hewan-hewan krustasea tersebut mencakup aspek biologi, seperti habitat (Sarong dan Wardiatno, 2013; Wardiatno et al., 2014), morfometrik (Wardiatno and Mashar, 2012), hubungan dan pertumbuhan alometrik (Mashar dan Wardiatno, 2013a,b; Muzammil et al., 2015; Pramithasari et al., 2016), fluktuasi kelimpahan dan dinamika populasi (Wardiatno and Mashar, 2013; Mashar et al., 2014; Hamid dan Wardiatno, 2015), aspek reproduksi (Wardiatno and Mashar 2010; Hamid et al., 2015a; Zairion et al., 2014a; Zairion et al., 2015; Edritanti et al., 2016) hingga potensi pemanfaatannya untuk kebutuhan makanan bergizi bagi manusia (Wardiatno et al., 2012; Santoso et al. 2015). Keanekaragaman dan keberadaan krustasea pun menjadi salah satu topik yang ditelaah (Mashar et al., 2014; Ardika et al., 2015; Mashar et al., 2015; Wardiatno et al., 2015a,b; Wardiatno et al., 2016a,b,c)

Rajungan merupakan salah satu jenis krustasea laut yang menjadi target aktivitas perikanan di Teluk Lasongko. Teluk Lasongko terletak di Pulau Muna dan secara administrasi termasuk dalam wilayah Kabupaten Buton Tengah Provinsi Sulawesi Tenggara. Luas perairan teluk ini sekitar $13.6 \mathrm{~km}^{2}$ dengan kedalaman berkisar antara 
$1 \mathrm{~m}$ hingga $50 \mathrm{~m}$ (adaptasi dari DKP Sulawesi Tenggara, 2003). Rajungan di perairan ini dapat ditemukan pada daerah intertidal dan subtidal yang ditumbuhi padang lamun dengan substrat umumnya terdiri dari pasir halus sampai pasir kasar serta serta pada kedalaman 31 meter dengan substrat berupa hamparan pasir halus (Hamid, 2011; Hamid et al., 2016). Perairan Teluk Lasongko merupakan daerah potensial untuk penangkapan rajungan. Penangkapan rajungan di perairan ini telah dilakukan secara intensif dan terjadi perubahan penggunaan alat tangkap rajungan yang dominan dari gillnet ke bubu. Penangkapan rajungan secara intensif dengan menggunakan bubu sebagai alat tangkap utama akan mempengaruhi distribusi ukuran rajungan pada suatu perairan (Johnston et al., 2011; Kunsook, 2011; Liu et al., 2014).

Distrubusi ukuran rajungan merupakan salah satu informasi yang dibutuhkan dalam pengelolaan rajungan, khususnya yang berkaitan dengan perlindungan habitat penting dalam siklus hidup rajungan dan zonasi pemanfaatannya pada suatu perairan (Zairion et al., 2014 ${ }^{\mathrm{a}}$ ). Berdasarkan penelitian sebelumnya menunjukkan distribusi ukuran rajungan bervariasi antar jenis kelamin dan antar lokasi perairan (Dhawan et al., 1976; Batoy et al.,1988; Sumpton et al., 1994; Razek et al., 2006; Sunarto 2012; Ernawati, 2013; Kurnia et al., 2014). Distribusi ukuran rajungan secara temporal juga ditemukan bervariasi pada lokasi perairan yang sama (Sumpton et al.,1994; Potter dan de Lestang, 2000; Sunarto et al., 2010; Sunarto, 2012; Ernawati, 2013), dan kedalaman dapat mempengaruhi distribusi ukuran rajungan pada suatu perairan (Chande dan Mgaya, 2003; Poter et al., 2001; Ernawati, 2013; Nugraheni et al., 2015; Zairion et al., 2014b). Distribusi ukuran rajungan berkaitan dengan aspek reproduksi rajungan, diantaranya pola distribusi tingkat kematangan gonad (Liu et al., 2014).

Penelitian distribusi ukuran lebar karapas rajungan secara spasial-temporal telah banyak dilakukan (diantaranya Batoy et al.,1988; Sumpton et al.,1994; Potter dan de Lestang, 2000; de Lestang et al., 2003; Razek et al., 2006; Ernawati, 2013; Kurnia et al., 2014; Johnston et al., 2011, 2014;
Zairion et al., 2014, 2015; Nugraheni et al., 2015). Sebaliknya, penelitian distribusi ukuran lebar karapas berdasarkan tingkat kematangan gonad (TKG) rajungan masih terbatas, diantaranya baru dilakukan oleh Razek et al. (2006) dan Liu et al. (2014) pada rajungan betina. Penelitian distribusi ukuran lebar karapas rajungan betina yang mengerami telur (betina ovigerous) telah dilakukan oleh Razek et al. (2006), Johnston et al. $(2011,2014)$ dan Zairion et al. (2014a, 2015), namun belum dipisahkan menurut warna telur yang dieraminya, yaitu kuning, orange, coklat dan abu-abu gelap (Hamid et al., 2015a,b, 2016).

Penelitian ini bertujuan untuk mengetahui distribusi ukuran lebar karapas secara spasial-temporal dan berdasarkan tingkat kematangan gonad rajungan jantan dan betina, serta distribusi kelas ukuran lebar karapas rajungan betina ovigerous berdasarkan warna telur yang dierami di Teluk Lasongko. Hasil penelitian ini diharapkan dapat digunakan sebagai dasar dalam pengelolaan rajungan dan sebagai rujukan untuk penelitian selanjutnya.

\section{Bahan dan Metode}

\section{Lokasi penelitian}

Penelitian ini dilakukan di perairan Teluk Lasongko, Kabupaten Buton Tengah dari bulan April 2013 sampai bulan Maret 2014. Teluk Lasongko terletak pada posisi $05^{\circ} 15^{\prime}-05^{\circ} 27^{\prime}$ LS dan $122^{\circ} 27^{\prime}-122^{\circ} 33^{\prime}$ BT (Gambar 1), dan bagian kepala teluk cenderung bersifat semi tertutup.

Pengambilan contoh dan prosedur pengukuran

Pengambilan contoh rajungan dilakukan pada tujuh stasiun dengan selang waktu setiap bulan selama satu tahun. Letak stasiun pengambilan contoh rajungan di mulai pada bagian kelapa teluk sampai mulut teluk (Gambar 1). Alat tangkap yang digunakan untuk menangkap rajungan adalah gillnet dasar dengan tiga ukuran mata jaring, yaitu 1.5, 2.5 dan 3.5 inci, kemudian dirangkai secara seri menjadi satu unit gillnet. Gillnet dipasang pada sore hari dan diangkat kembali pada pagi hari. 


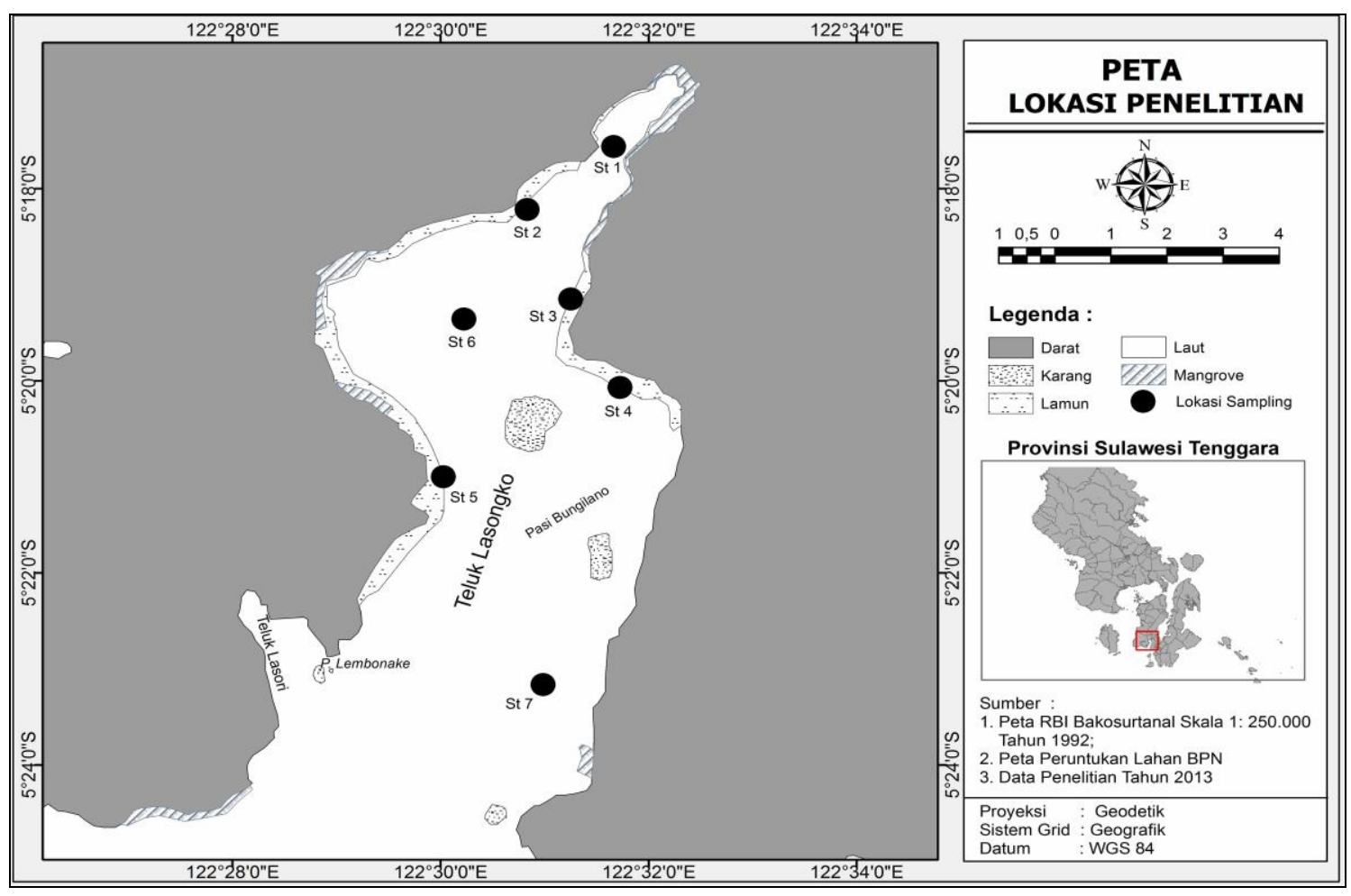

Gambar 1. Peta lokasi penelitian dan stasiun pengambilan contoh rajungan di Teluk Lasongko

Rajungan yang tertangkap dipisahkan antara jantan dan betina serta rajungan betina ovigerous. Setiap ekor rajungan pada masing-masing kelompok tersebut diukur lebar karapasnya dengan menggunakan kaliper (Vernier Caliper 0-150 mm x 0.05) berketelitian $0,01 \mathrm{~mm}$. Selanjutnya, berat tubuh setiap rajungan tersebut ditimbang dengan menggunakan timbangan digital (Xon Med Digital Scale) berketelitian 0.01 gram.

Setiap contoh rajungan yang berukuran lebar karapas $>60 \mathrm{~mm}$ dibuka karapasnya untuk diamati perkembangan tingkat kematangan gonadnya. Perkembangan TKG rajungan betina ditentukan dari perubahan morfologi, warna dan penyebaran ovarium menempati daerah hepatik. Tingkat kematangan gonad rajungan betina dibagi dalam empat tingkatan (de Lestang et al., 2003b; Kamrani et al., 2010; Ikhwanuddin et al., 2012), yaitu belum matang (TKG I), awal pematangan (TKG II), pematangan akhir (TKG III), dan matang (TKG IV). Perkembangan TKG rajungan jantan ditentukan dari perubahan morfologi, warna serta sebaran testis dan vas deferen secara visual dengan alat bantu kaca pembesar (lop), dan dibagi dalam tiga tingkatan (Sukumaran dan
Neelakantan,1998; de Lestang et al., 2003b; Johnson et al., 2011), yaitu belum matang (TKG I), sedang matang (TKG II), dan matang (TKG III). Rajungan jantan dan betina yang gonadnya belum berkembang dikategorikan sebagai TKG nol (0).

\section{Analisis Data}

Berdasarkan pada sebaran data ukuran lebar karapas rajungan jantan dan betina yang diperoleh, maka ditentukan distribusi kelas ukuran kedua jenis kelamin rajungan dengan lebar kelas antar kelas ukuran sebesar $10 \mathrm{~mm}$. Distribusi kelas ukuran lebar karapas rajungan jantan dan betina dikelompokkan berdasarkan spasial (stasiun), temporal (periode sampling), dan tingkat kematangan gonad, serta rajungan betina ovigerous berdasarkan warna telur yang dierami. Distribusi kelas ukuran lebar karapas rajungan jantan dan betina secara spasial-temporal juga dikelompokkan dalam tiga kategori, yaitu rajungan tahap juvenil dan muda dengan ukuran lebar karapas berkisar 49,8-89,8 $\mathrm{mm}$, rajungan tahap dewasa dengan ukuran lebar karapas berkisar 98,9-129,8 $\mathrm{mm}$, dan rajungan tahap tua dengan ukuran lebar karapas berkisar 
129,9-169,8 mm (adaptasi dari Wulandari 2014; Nugraheni et al., 2015).

\section{Hasil dan Pembahasan}

\section{Deskripsi ukuran tubuh rajungan}

Total jumlah contoh rajungan jantan yang dianalisis sebanyak 606 ekor dengan lebar karapas berkisar 49.80-147.70 mm dan berat berkisar 6,06-241,04 g, dan rajungan betina sebanyak 496 ekor dengan lebar karapas berkisar 52,10-166,20 mm dan berat berkisar 9,95-268,75 g (Tabel 1). Jumlah contoh rajungan betina ovigerous sebanyak 168 ekor dengan lebar karapas berkisar 86,60-162,30 $\mathrm{mm}$ dan berat

Tabel 1. Deskripsi ukuran tubuh rajungan jantan, betina dan betina ovigerous di Teluk Lasongko

\begin{tabular}{lcccccc}
\hline \multirow{2}{*}{$\begin{array}{l}\text { Dimensi } \\
\text { ukuran }\end{array}$} & \multicolumn{2}{c}{ Jantan $(\mathrm{n}=606)$} & \multicolumn{2}{c}{ Betina $(\mathrm{n}=496)$} & \multicolumn{2}{c}{ Betina ovigerous $(\mathrm{n}=168)^{*}$} \\
\cline { 2 - 6 } & $\begin{array}{c}\text { Lebar karapas } \\
(\mathrm{mm})\end{array}$ & Berat $(\mathrm{g})$ & $\begin{array}{c}\text { Lebar karapas } \\
(\mathrm{mm})\end{array}$ & Berat $(\mathrm{g})$ & $\begin{array}{c}\text { Lebar karapas } \\
(\mathrm{mm})\end{array}$ & Berat $(\mathrm{g})$ \\
\hline Rataan & 107,40 & 89,49 & 108,17 & 87,37 & 118,64 & 128,18 \\
Terbesar & 147,70 & 241,04 & 166,20 & 268,75 & 162,30 & 314,22 \\
Terkecil & 49,80 & 6,06 & 52,10 & 9,95 & 86,60 & 42,75 \\
SD & 14,90 & 38,03 & 17,92 & 42,74 & 12,11 & 43,33 \\
Modus & 111,10 & 131,44 & 101,20 & 37,65 & 115,10 & 99,53 \\
\hline \multicolumn{1}{c}{$*$ data diolah dari Hamid et al. (2016) } & SD: simpangan baku, & $\mathrm{n}$ : jumlah
\end{tabular}

Distribusi ukuran lebar karapas secara spasial

Secara umum, ukuran lebar karapas rajungan jantan dan betina di Teluk Lasongko secara spasal masing-masing terdisribusi pada 10 dan 12 kelas ukuran, serta jumlah kelas ukuran bervariasi antar stasiun (Gambar 2). Rajungan jantan tidak ditemukan pada kelas ukuran lebar karapas dengan nilai tengah 154,85 mm dan 164,85 $\mathrm{mm}$. Ukuran lebar karapas rajungan jantan yang ditemukan pada setiap stasiun terdistribusi pada 5-9 kelas ukuran, sedangkan rajungan betina pada 7-9 kelas ukuran. Jumlah kelas ukuran lebar karapas rajungan jantan dan betina terbanyak ditemukan pada stasiun 1, sedangkan jumlah kelas ukuran tersedikit untuk rajungan jantan ditemukan di stasiun 3 dan rajungan betina pada stasiun 2 . Rajungan jantan dan betina tahap juvenil dan muda $(49,8-89,8 \mathrm{~mm})$ dan tahap tua $(129,9-169,8$ berkisar 42,75-314,22 g (Hamid et al., 2016).

Pada Tabel 1 terlihat bahwa rataan lebar karapas rajungan jantan lebih kecil dari pada rajungan betina, dan hal ini identik dengan yang ditemukan di Teluk Kun Krabaen Bay, Thailand (Kunsook, 2011). Sebalikya, di Teluk Moreton, QueenslandAustralia ditemukan ukuran lebar karapas rajungan betina lebih kecil dari pada rajungan jantan (Sumpton et al., 1994). Kondisi rataan berat tubuh rajungan pada penelitian ini identik dengan yang ditemukan di Estuari Zuari, India (Dhawan et al., 1976), yaitu ukuran rajungan jantan lebih besar dari pada rajungan betina, sedangkan yang ditemukan di pantai Leyte dan Bohol, Filipina rajungan betina lebih berat dari pada rajungan jantan (Batoy et al.,1988).

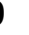


Tabel 2. Frekuensi rajungan jantan dan betina pada tahap juvenil, dewasa dan tua pada setiap stasiun di Teluk Lasongko

\begin{tabular}{ccccccc}
\hline \multirow{3}{*}{ Stasiun } & \multicolumn{5}{c}{ Frekuensi $(\%)$ rajungan jantan dan betina pada setiap kategori } \\
\cline { 2 - 7 } & Juvenil' $(49,8-89,8 \mathrm{~mm})$ & Dewasa $(98,9-129,8 \mathrm{~mm})$ & Tua $(129,9-169,8 \mathrm{~mm})$ \\
\cline { 2 - 7 } & Jantan & Betina & Jantan & Betina & Jantan & Betina \\
\hline 1 & 21,9 & 27,03 & 76,64 & 72,07 & 1,46 & 0,90 \\
2 & 19,4 & 31,01 & 79,14 & 68,99 & 1,44 & - \\
3 & - & 3,75 & 94,29 & 81,25 & 5,71 & 15,00 \\
4 & 2,56 & 0,92 & 89,74 & 78,9 & 7,69 & 20,18 \\
5 & 4,00 & 5,56 & 89,33 & 86,11 & 6,57 & 8,33 \\
6 & 11,11 & 1,32 & 77,78 & 86,84 & 11,11 & 11,84 \\
7 & - & - & 80,77 & 66,67 & 19,23 & 33,33 \\
\hline
\end{tabular}

- =tidak ditemukan ${ }^{*}$ ) =juvenil dan muda
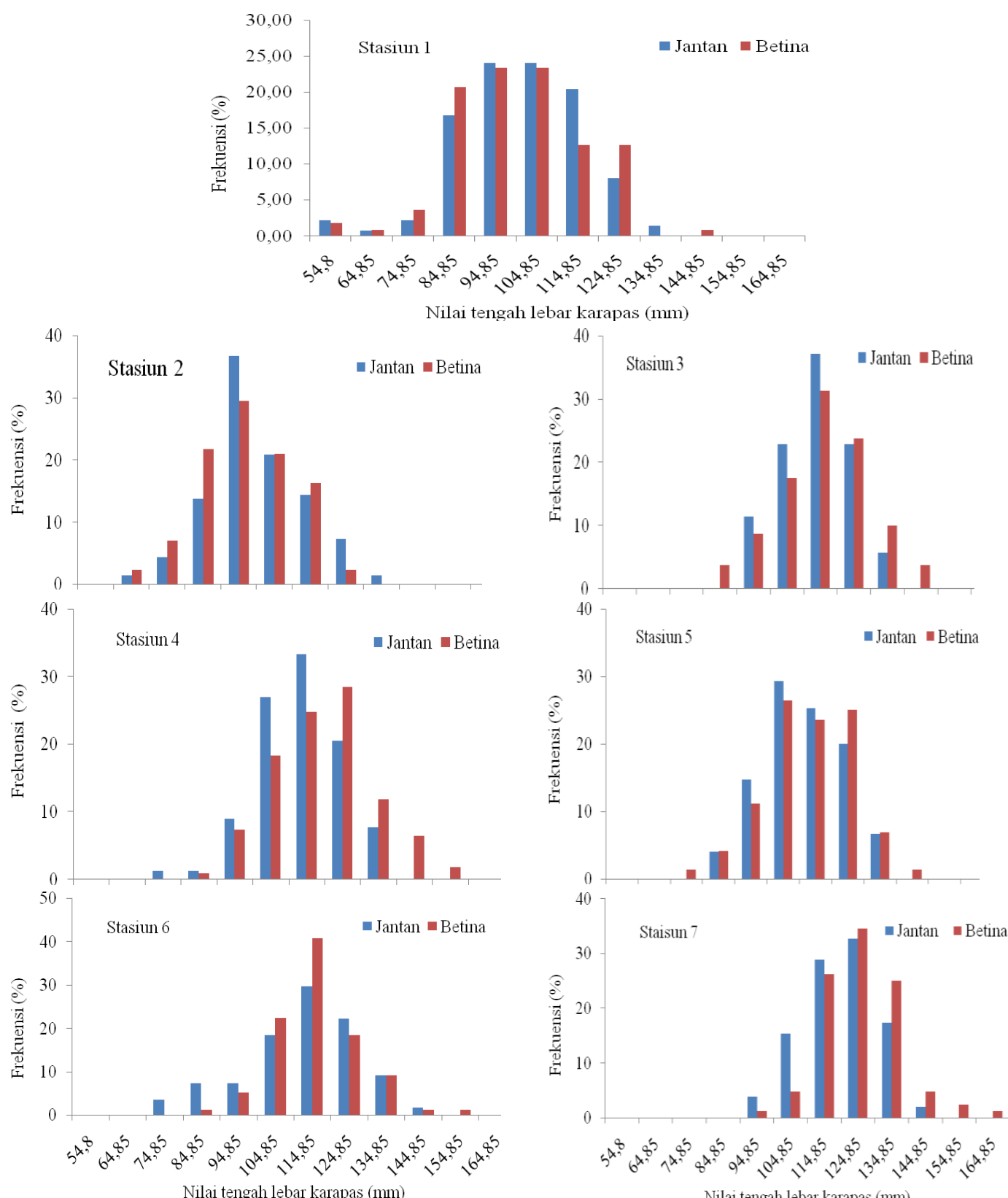

Gambar 2. Distribusi frekuensil kelas ukuran lebar karapas rajungan jantan dan betina secara spasial di Teluk Lasongko 
Frekuensi rajungan jantan dan betina pada setiap kelas ukuran lebar karapas yang ditemukan pada setiap stasiun juga bervariasi (Gambar 2). Rajungan jantan dan betina tahap juvenil dan muda banyak ditemukan di stasiun 1 dan 2 . Frekuensi rajungan jantan dan betina tahap juvenil dan muda di staisun 1 masing-masing sebasar $21,90 \%$ dan $27,03 \%$, serta di stasiun 2 untuk rajungan jantan sebesar $19,40 \%$ dan betina sebesar $31,01 \%$ dari total jumlah rajungan pada setiap stasiun. Kedua stasiun tersebut sebaiknya perlu dilindungi karena diduga sebagai lokasi pembesaran rajungan di Teluk Lasongko. Frekuensi rajungan jantan tahap tua pada setiap stasiun berkisar 1,44-19,23 \%, tertinggi ditemukan di stasiun 7 dan terendah di stasiun 1 dan 2 (Tabel 2). Jumlah kelas ukuran rajungan betina tahap tua yang ditemukan pada setiap stasiun berkisar 1- 4 kelas ukuran, dan tidak ditemukan di stasiun 2 (Gambar 2). Frekuensi rajungan jantan tahap dewasa pada setiap stasiun berkisar 76,64-94,29\%, tertinggi ditemukan di stasiun 3 dan terendah di stasiun 1, sedangkan frekuensi rajungan betina tahap dewasa berkisar $66,67-86,84 \%$, tertinggi ditemukan di stasiun 6 dan terendah di stasiun 7 .

Ukuran lebar karapas rajungan jantan dan betina secara spasial yang ditemukan pada stasiun 1 dan 2 tergolong berukuran kecil, kemudian yang ditemukan pada stasiun 3, 4, 5 dan 6 tergolong berukuran sedang, dan pada stasiun 7 tergolong berukuran besar. Adanya variasi distribusi kelas ukuran lebar karapas secara spasial berkaitan dengan variasi kondisi habitat seperti keadaan substrat (komposisi fraksi sedimen dan tipe substrat) dan kepadatan padang lamun serta keadaan kualitas air seperti kecepatan arus, salinitas dan kecerahan antar stasiun. Kondisi habitat rajungan di stasiun 1 dan 2, bertipe substrat pasir dengan fraksi sedimen didominasi oleh pasir sangat kasar dan pasir kasar, ditumbuhi lamun dengan kepadatan rendah serta kecerahan dan salinitasnya relatif lebih rendah dibandingkan dengan lima stasiun lainnya. Tipe substrat habitat rajungan di stasiun 7 adalah lempung, dasar perairan berupa hamparan pasir, kondisi airnya lebih cerah serta salinitasnya lebih tinggi, dan tekanan penangkapan rajungan di stasiun 7 lebih rendah dari pada enam stasiun lainnya. Adanya variasi ukuran lebar karapas rajungan pada suatu perairan juga dipengaruhi oleh ketersediaan makanan, migrasi, tekanan penangkapan, jenis alat yang digunakan pada pengambilan data (Potter dan de Lestang 2000; Chande dan Mgaya 2003; Johnson et al., 2011; Kunsook, 2011; Sunarto 2012; Ernawati 2013; Nugraheni et al., 2015).

Ukuran lebar karapas rajungan jantan dan betina yang ditemukan pada stasiun dengan kondisi perairan lebih dalam (stasiun 7) lebih besar dibandingkan dengan pada stasiun yang dangkal (1 dan 2, 5). Hal ini identik dengan yang ditemukan di perairan Selat Makassar, Sulawesi Selatan (Adam et al., 2006), Pati (Ernawati, 2013; Nugraheni et al., 2015), Wedung-Demak (Wulandari et al., 2014) dan Lampung Timur (Zairon et al., 2014a,b), serta di perairan Shark Bay, Australia (Potter et al., 2001). Kisaran distribusi ukuran lebar karapas rajungan jantan dan betina di Teluk Lasongko lebih besar dari pada yang ditemukan di perairan Lampung Timur bagian Teluk PGN (Kurnia et al. 2014), namun lebih kecil dari pada yang dilaporkan oleh Zairon et al. (2014b) di perairan Lampung Timur pada lokasi yang lebih dalam, dan juga Cokburn Sound, Australia (Johnston et al., 2011).

Distribusi ukuran lebar kaparas secara temporal

Distribusi frekuensi ukuran lebar karapas rajungan jantan dan betina secara temporal di Teluk Lasongko tertera pada Gambar 3. Lebar karapas rajungan jantan yang ditemukan pada setiap bulan terdistribusi pada 4-9 kelas ukuran, terbanyak ditemukan pada bulan Februari dan tersedikit pada bulan Oktober. Lebar karapas rajungan betina pada setiap bulan terdistribusi pada 6-12 kelas ukuran, terbanyak ditemukan pada bulan Mei dan tersedikit pada bulan Oktober. Jumlah kelas ukuran dan frekuensi rajungan jantan dan betina pada setiap kelas ukuran lebar karapas di Teluk Lasongko secara temporal ditemukan bervariasi. Distribusi frekuensi ukuran lebar karapas rajungan jantan dan betina secara temporal umumnya juga didominasi oleh empat kelas ukuran dengan nilai tengah berkisar 94,85-124,85 mm, dengan pola distribusi kelas ukurannya berbeda pada setiap bulan (Gambar 3).

Distribusi ukuran lebar karapas rajungan jantan dan betina di Teluk Lasongko ditemukan mengalami pergeseran secara temporal. Rajungan jantan yang ditemukan pada bulan Oktober, November dan Desember banyak terdistribusi pada kelas ukuran yang besar, sedangkan 
rajungan betina dengan kelas ukuran besar banyak ditemukan pada bulan Oktober, November, Maret, September dan Desember. Rajungan jantan yang ditemukan pada bulan April, Mei, Juli, September, Februari dan Maret banyak terdistribusi pada kelas ukuran yang kecil, sedangkan rajungan betina berukuran kecil banyak ditemukan pada bulan April. Pergeresan kelas ukuran rajungan secara temporal (antar periode penangkapan) juga
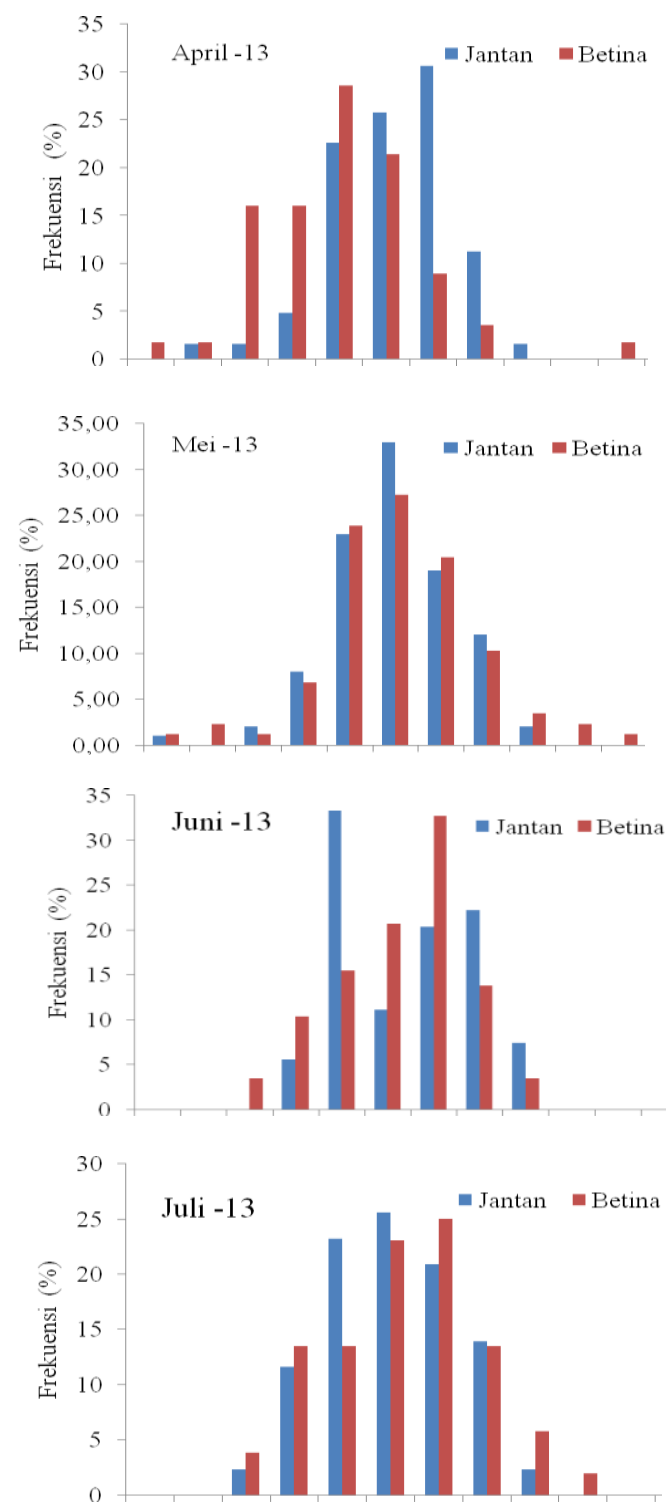

ditemukan di perairan Brebes dan Pati (Sunarto 2012; Ernawati 2013), Laguna Bardawil-Mesir (Razek et al., 2006) serta di perairan Cokburn Sound dan Shark Bay, Australia (Johnston et al., 2011, 2014). Rajungan jantan dan betina di perairan Pati yang berukuran besar banyak ditemukan pada bulan September sampai November, sedangkan yang berukuran kecil ditemukan pada bulan Januari dan Februari (Ernawati 2013).
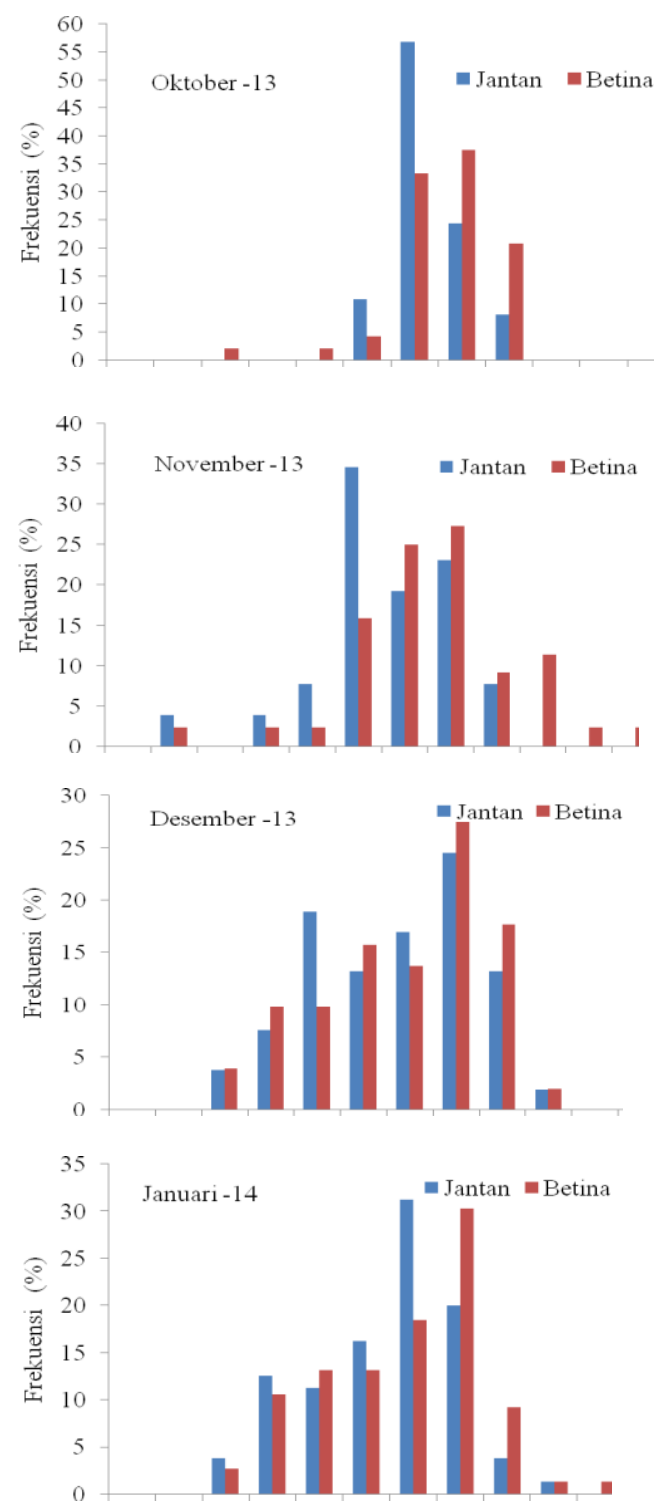

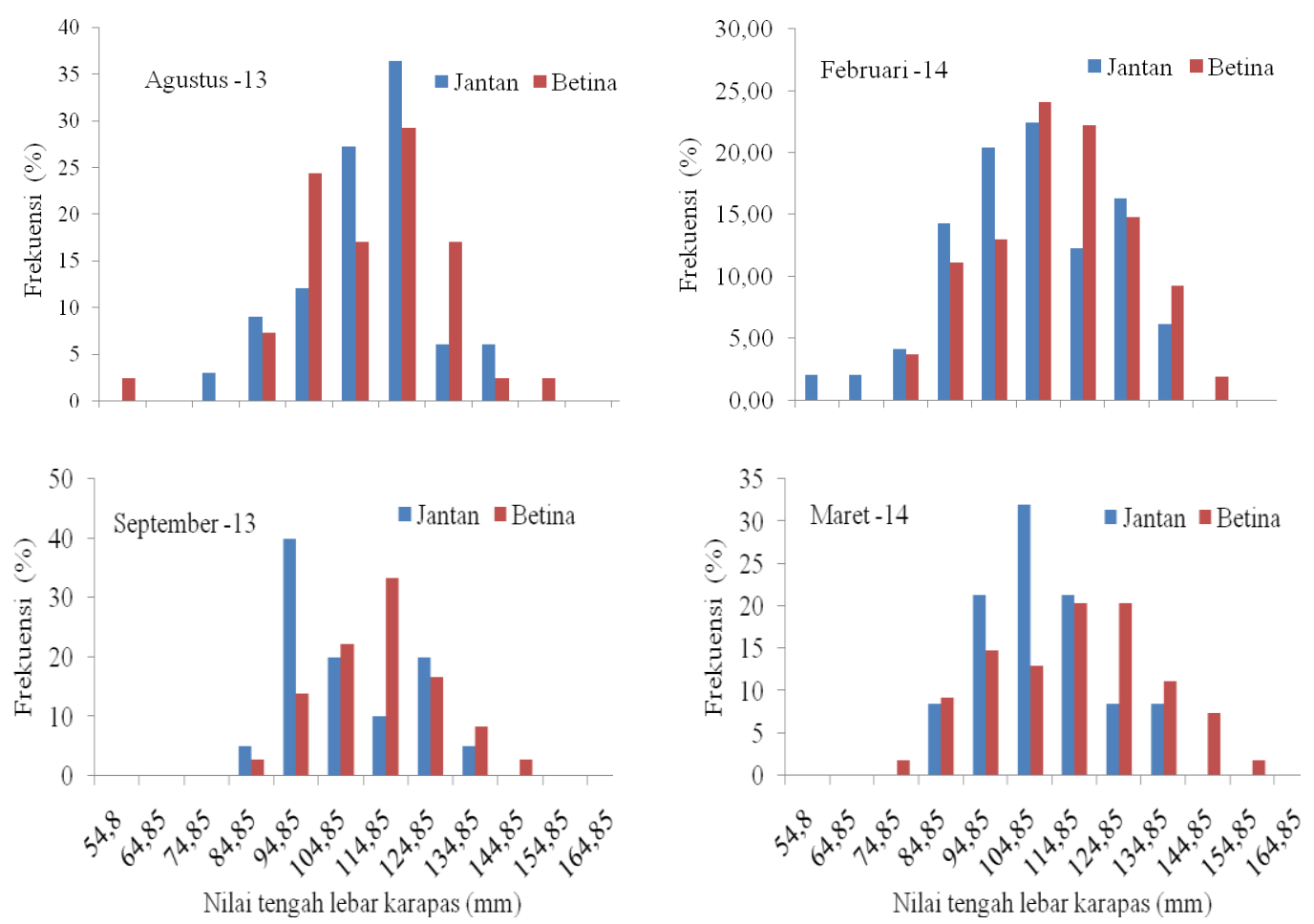

Gambar 3. Distribusi frekuensi kelas ukuran lebar karapas rajungan jantan dan betina secara temporal di Teluk Lasongko

Rajungan jantan tahap juvenil dan muda yang ditemukan pada setiap bulan terdiri dari 1-3 kelas ukuran dengan frekuensi berkisar 0,56-22,45\%, tertinggi ditemukan pada bulan Februari, dan terendah pada bulan Juni. Rajungan betina tahap tahap juvenil dan muda yang ditemukan pada setiap bulan terdiri dari 1-4 kelas ukuran dengan frekuensi berkisar $2,08-19,64 \%$ tertinggi ditemukan pada bulan April dan terendah pada bulan Oktober. Rajungan jantan tahap tua pada setiap bulan ditemukan terdiri dari 1-2 kelas ukuran lebar karapas dengan frekuensi berkisar $1,61-15,09 \%$, tertinggi ditemukan pada bulan Desember dan terendah pada bulan April. Rajungan betina tahap tua terdiri dari 1-4 kelas ukuran dengan frekuensi berkisar $3,45-25,00 \%$, tertinggi ditemukan pada bulan November dan terendah pada bulan Juni (Tabel 3 dan Gambar 3). Rajungan jantan dan betina yang ditemukan di Teluk Lasongko didominasi oleh tahap dewasa dengan frekuensi pada setiap bulan masingmasing berkisar $71,43-90,32 \%$ dan 66,67 $87,80 \%$. Hal ini sesuai yang dilaporkan sebelumnya bahwa rajungan di perairan ini pada setiap bulan terdiri dari tahap juvenil, dewasa dan tua, namun didominasi oleh kelompok ukuran dewasa (Hamid dan Yusli, 2015).

Distribusi frekuensi kelas ukuran lebar karapas rajungan jantan dan betina pada kelas ukuran yang sama yang ditemukan pada bulan Mei dan Januari umumnya lebih tinggi dari pada yang tertangkap pada 10 bulan yang lain, karena jumlah rajungan jantan dan betina yang ditemukan pada kedua bulan tersebut lebih banyak dari pada 10 bulan yang lain (Gambar 3). Jumlah rajungan jantan yang ditemukan pada bulan Mei sebesar 100 ekor dan pada bulan Januari sebanyak 80 ekor, dan keduanya terdistribusi pada 8 kelas ukuran lebar karapas. Rajungan jantan yang ditemukan pada bulan Januari terdistribusi pada kelas ukuran lebih besar dari pada rajungan jantan yang ditemukan pada Mei. Nilai tengah lebar karapas kelas ukuran rajungan jantan yang ditemukan pada Mei berkisar $54,8-134,85 \mathrm{~mm}$, sedangkan yang ditemukan pada bulan Januari berkisar 74,85-144,85 mm. Jumlah rajungan betina yang ditemukan pada bulan Mei sebanyak 89 ekor dan tersebar pada 12 kelas ukuran lebar karapas, sedangkan pada bulan Januari ditemukan sebanyak 76 ekor dan tersebar pada 9 kelas ukuran lebar karapas (Gambar 3). 
Tabel 3. Frekuensi rajungan jantan dan betina pada tahap juvenil, dewasa dan tua pada setiap bulan di Teluk Lasongko

\begin{tabular}{lcccccc}
\hline Bulan & \multicolumn{6}{c}{ Frekuensi $(\%)$ rajungan jantan dan betina pada setiap tahap } \\
\cline { 2 - 7 } & Juvenil') $(49,8-89,8 \mathrm{~mm})$ & Dewasa & $(98,9-129,8 \mathrm{~mm})$ & Tua $(129,9-169,8 \mathrm{~mm})$ \\
\cline { 2 - 7 } & Jantan & Betina & Jantan & Betina & Jantan & Betina \\
\hline April -13 & 8,06 & 19,64 & 90,32 & 75,00 & 1,61 & 5,36 \\
Mei -13 & 11,00 & 11,36 & 87,00 & 81,82 & 2,00 & 7,95 \\
Juni -13 & 0,56 & 13,79 & 87,04 & 82,76 & 7,41 & 3,45 \\
Juli -13 & 13,95 & 17,31 & 83,72 & 75,00 & 2,33 & 7,69 \\
Agustus -13 & 5,00 & 9,76 & 81,82 & 87,80 & 6,06 & 4,88 \\
September-13 & 5,00 & 2,78 & 90,00 & 86,11 & 5,00 & 11,11 \\
Oktober -13 & - & 2,08 & 91,89 & 77,08 & 8,11 & 20,83 \\
November -13 & 7,69 & 4,55 & 84,62 & 70,45 & 7,69 & 25,00 \\
Desember-13 & 11,32 & 13,73 & 73,58 & 66,67 & 15,09 & 19,61 \\
Januari -14 & 16,25 & 13,16 & 78,75 & 75,00 & 5,00 & 11,84 \\
Februari -14 & 22,45 & 14,81 & 71,43 & 74,07 & 6,12 & 11,11 \\
Maret -14 & 8,51 & 11.11 & 82,98 & 68,52 & 8,51 & 20,37 \\
\hline
\end{tabular}
- =tidak ditemukan ${ }^{*}$ ) =juvenil dan muda

Distribusi ukuran lebar karapas berdasarkan tingkat kematangan gonad

Lebar karapas rajungan jantan dengan gonad belum berkembang (TKG 0) terdistribusi pada 9 kelas ukuran dengan nilai tengah 54,3-134,85 mm, sedangkan lebar karapas rajungan betina terdistribusi pada 11 kelas ukuran dengan nilai tengah 54,3-164,85 mm (Tabel 4 dan 5). Kisaran ukuran lebar karapas rajungan betina dengan TKG 0 yang ditemukan pada penelitian ini lebih besar dari pada yang ditemukan di Laguna Badwil, Mesir, yaitu sebesar 35,0-115,0 mm (Razek et al., 2006). Frekuensi rajungan jantan TKG 0 tertinggi ditemukan pada kelas ukuran lebar karapas dengan nilai tengah $104,85 \mathrm{~mm}$ dan terendah pada $134,85 \mathrm{~mm}$, sedangkan untuk rajungan betina frekuensi tertinggi ditemukan pada kelas ukuran lebar karapas dengan nilai tengah $99,85 \mathrm{~mm}$ dan terendah pada ukuran $164,85 \mathrm{~mm}$.

Tabel 4. Distribusi frekuensi kelas ukuran lebar karapas rajungan jantan pada setiap TKG di Teluk Lasongko

\begin{tabular}{|c|c|c|c|c|c|c|}
\hline \multirow{2}{*}{$\begin{array}{l}\text { Selang ukuran } \\
(\mathrm{mm})\end{array}$} & \multirow{2}{*}{$\begin{array}{c}\text { Nilai } \\
\text { tengah }(\mathrm{mm})\end{array}$} & \multicolumn{4}{|c|}{ Frekuensi setiap TKG (ekor) } & \multirow{2}{*}{$\begin{array}{l}\text { Jumlah } \\
\text { (ekor) }\end{array}$} \\
\hline & & $\left.0^{*}\right)$ & $\mathrm{I}$ & II & III & \\
\hline $49.8-59.8$ & 54,3 & 4 & & & & 4 \\
\hline $59.9-69.8$ & 64,85 & 2 & & & & 2 \\
\hline $69.9-79.8$ & 74,85 & 14 & 1 & & & 15 \\
\hline 79.9-89.8 & 84,85 & 25 & 11 & 12 & 3 & 51 \\
\hline 89.9-99.8 & 99,85 & 28 & 29 & 38 & 24 & 119 \\
\hline $99.9-109.8$ & 104,85 & 34 & 18 & 55 & 30 & 137 \\
\hline 109.9-119.8 & 114,85 & 18 & 13 & 66 & 51 & 148 \\
\hline $119.9-129.8$ & 124,85 & 12 & 7 & 21 & 55 & 95 \\
\hline $129.9-139.8$ & 134,85 & 1 & 1 & 8 & 23 & 33 \\
\hline $139.9-149.8$ & 144,85 & & & 1 & 1 & 2 \\
\hline Jumlah (ekor) & & 137 & 80 & 202 & 187 & 606 \\
\hline
\end{tabular}

'Tonad belum berkembang 
Tabel 5. Distribusi frekuensi kelas ukuran lebar karapas rajungan betina pada setiap TKG di Teluk Lasongko

\begin{tabular}{|c|c|c|c|c|c|c|c|}
\hline \multirow{2}{*}{$\begin{array}{l}\text { Selang ukuran } \\
(\mathrm{mm})\end{array}$} & \multirow{2}{*}{$\begin{array}{l}\text { Nilai tengah } \\
(\mathrm{mm})\end{array}$} & \multicolumn{5}{|c|}{ Frekuensi setiap TKG (ekor) } & \multirow{2}{*}{$\begin{array}{l}\text { Jumlah } \\
\text { (ekor) }\end{array}$} \\
\hline & & $0^{n}$ & $\mathrm{I}$ & II & III & IV & \\
\hline $49.8-59.8$ & 54,3 & 2 & & & & & 2 \\
\hline $59.9-69.8$ & 64,85 & 4 & & & & & 4 \\
\hline $\begin{array}{l}69.9-79.8 \\
79.9-89.8\end{array}$ & $\begin{array}{l}74,85 \\
84.85\end{array}$ & $\begin{array}{l}15 \\
45\end{array}$ & $\begin{array}{l}2 \\
6\end{array}$ & 1 & 3 & & $\begin{array}{l}17 \\
55\end{array}$ \\
\hline 89.9-99.8 & 99,85 & 49 & 19 & 7 & 5 & 6 & 86 \\
\hline $99.9-109.8$ & 104,85 & 22 & 22 & 16 & 19 & 20 & 99 \\
\hline $109.9-119.8$ & 114,85 & 11 & 22 & 23 & 22 & 27 & 105 \\
\hline $119.9-129.8$ & 124,85 & 4 & 8 & 9 & 20 & 34 & 75 \\
\hline $129.9-139.8$ & 134,85 & 6 & 1 & 4 & 9 & 15 & 35 \\
\hline $139.9-149.8$ & 144,85 & 2 & & 2 & 1 & 7 & 12 \\
\hline $149.9-159.8$ & 154,85 & & & 1 & 1 & 3 & 5 \\
\hline $159.9-169.8$ & 164,85 & 1 & & & & & 1 \\
\hline \multicolumn{2}{|c|}{ Jumlah (ekor) } & 160 & 80 & 64 & 80 & 112 & 496 \\
\hline
\end{tabular}

'Gonad belum berkembang

Secara umum, kelas ukuran lebar karapas rajungan jantan dengan kondisi gonad telah berkembang (TKG I-III) dan juga rajungan betina (TKG I-IV) banyak ditemukan pada nilai tengah 99,85-124,85 $\mathrm{mm}$. Ukuran lebar kaparas rajungan jantan yang belum matang gonad (TKG I dan II) tersebar pada kelas ukuran dengan nilai tengah 74,85-144,85 mm, sedangkan rajungan betina berkisar $74,85-154,85 \mathrm{~mm}$ (Tabel 4 dan 5) dan frekuensi keduanya ditemukan bervariasi pada setiap kelas ukuran. Frekuensi rajungan jantan yang belum matang gonad tertinggi ditemukan pada lebar karapas dengan nilai tengah $114,85 \mathrm{~mm}$, serta terendah pada $74,85 \mathrm{~mm}$ dan $144,85 \mathrm{~mm}$, sedangkan untuk rajungan betina tertinggi ditemukan pada lebar karapas dengan nilai tengah 114,85 mm dan terendah pada $154,85 \mathrm{~mm}$. Frekuensi rajungan jantan dan betina yang belum matang gonad pada kisaran lebar karapas dengan nilai tengah $74,85-114,85 \mathrm{~mm}$ ditemukan semakin meningkat dengan meningkatnya ukuran lebar karapas (Tabel 4 dan 5). Kisaran nilai tengah ukuran lebar karapas rajungan betina yang belum matang gonad yang ditemukan pada penelitian ini lebih besar dari pada yang ditemukan di Laguna Badwil, Mesir, yaitu sebesar 75,0115,0 mm (Razek et al., 2006).

Kisaran kelas ukuran lebar karapas rajungan jantan yang matang gonad (TKG III) ditemukan pada nilai tengah 84,85 $144,85 \mathrm{~mm}$, dan rajungan betina yang matang gonad (TKG III dan IV) ditemukan pada nilai tengah lebar karapas 84,85$154,85 \mathrm{~mm}$ dengan frekuensi keduanya bervariasi antar kelas ukuran. Frekuensi rajungan jantan dan betina yang matang gonad tertinggi ditemukan pada kelas ukuran lebar karapas dengan nilai tengah $124,85 \mathrm{~mm}$. Frekuensi terendah rajungan jantan dan betina yang matang gonad masing-masing ditemukan pada kelas ukuran lebar karapas dengan nilai tengah $144,85 \mathrm{~mm}$ dan $84,85 \mathrm{~mm}$. Frekuensi rajungan jantan dan betina yang matang gonad pada kelas ukuran lebar karaps dengan nilai tengah $\geq 134,85 \mathrm{~mm}$ ditemukan semakin menurun. Sebaliknya, frekuensi rajungan jantan dan betina yang matang gonad pada kelas ukuran lebar karapas dengan nilai tengah berkisar 84,85-124,85 $\mathrm{mm}$ semakin meningkat dengan meningkatnya ukuran lebar karapas. Pola peningkatan frekuensi rajungan betnia yang matang gonad tersebut identik dengan yang ditemukan di Teluk Beibu, Cina dan peningkatan yang tinggi pada rajungan betina yang matang gonad $(\geq 84.6 \%)$ terjadi ukuran lebar karapas $>106 \mathrm{~mm}$ (Liu et al., 2014). Kisaran ukuran lebar karapas rajungan betina yang matang gonad yang ditemukan pada penelitian ini lebih besar dari pada yang ditemukan di Laguna Badwil, Mesir, yaitu sebesar 85,0-135,0 mm (Razek et al., 2006) dan relatif sama dengan yang ditemukan di Teluk Beibu, Cina (Liu et al., 2014). 
Distribusi ukuran rajungan betina ovigerous

Distribusi frekuensi kelas ukuran lebar karapas rajungan betina ovigerous di Teluk Lasongko berdasarkan warna telur yang dierami tertera pada Tabel 6. Ukuran lebar karapas rajungan betina ovigerous terdistribusi pada 8 kelas ukuran, serta jumlah kelas ukuran dan frekuesinya bervariasi antar warna telur yang dierami. Ukuran lebar karapas rajungan betina ovigerous didominasi oleh 3 kelas ukuran dengan nilai tengah berkisar 104,85-124,85 $\mathrm{mm}$. Pada kisaran kelas ukuran tersebut frekuensi rajungan betina ovigerous semakin meningkat dengan meningkatnya kelas ukuran untuk keempat warna telur yang dierami. Kisaran ukuran lebar karapas rajungan betina ovigerous yang ditemukan pada penelitian ini lebih besar dari pada yang ditemukan di Laguna Badwil, Mesir, yaitu berkisar 95,0-125,0 mm (Razek et al., 2006) dan relatif sama dengan yang ditemukan di perairan Lampung Timur (Zairion et al., 2014a, 2015) dan di PeelHarvey, Australia (Johnston et al., 2014), dan lebih kecil dibandingkan dengan yang ditemukan di Cokburn Sound, Australia (Johnston et al., 2011).

Tabel 6. Distribusi frekuensi kelas ukuran lebar karapas rajungan betina ovegrous berdasarkan warna telur yang dierami di Teluk Lasongko

\begin{tabular}{|c|c|c|c|c|c|c|}
\hline \multirow{2}{*}{$\begin{array}{l}\text { Kelas ukuran } \\
\qquad(\mathrm{mm})\end{array}$} & \multirow{2}{*}{$\begin{array}{l}\text { Nilai tengah } \\
\qquad(\mathrm{mm})\end{array}$} & \multicolumn{4}{|c|}{ Frekuensi setiap warna telur (ekor) } & \multirow{2}{*}{$\begin{array}{c}\text { Jumlah } \\
\text { (ekor) }\end{array}$} \\
\hline & & Kuning & Orange & coklat & Abu-abu gelap & \\
\hline $79.9-89.8$ & 84,85 & 1 & 1 & & & 2 \\
\hline 89.9-99.8 & 99,85 & 4 & 3 & 1 & 1 & 9 \\
\hline $99.9-109.8$ & 104,85 & 9 & 7 & 5 & 5 & 26 \\
\hline 109.9-119.8 & 114,85 & 24 & 11 & 11 & 8 & 54 \\
\hline $119.9-129.8$ & 124,85 & 10 & 18 & 12 & 12 & 52 \\
\hline 129.9-139.8 & 134,85 & 6 & 6 & 1 & 5 & 18 \\
\hline 139.9-149.8 & 144,85 & 2 & 2 & 1 & 1 & 6 \\
\hline 149.9-159.8 & 154,85 & & & & & \\
\hline 159.9-169.8 & 164,85 & 1 & & & & 1 \\
\hline \multicolumn{2}{|c|}{ Jumlah (ekor) } & 57 & 48 & 31 & 32 & 168 \\
\hline
\end{tabular}

Keempat warna telur rajungan betina ovigerous di Teluk Lasongko dapat ditemukan di intertidal bagian bawah yang ditumbuhi lamun sampai kedalaman 31 meter dengan dasar perairan berupa hamparan pasir (Hamid et al., 2016). Ukuran lebar karapas rajungan betina ovigerous yang ditemukan di intertidal yang ditumbuhi lamun umumnya lebih kecil dibandingkan dengan yang temukan pada lokasi yang dalam. Pola distribusi ukuran lebar karapas rajungan betina ovigerous terhadap kedalaman perairan tersebut identik dengan yang ditemukan di perairan Lampung Timur (Zairion et al., 2014a).

\section{Kesimpulan}

Ukuran lebar karapas rajungan jantan, betina dan betina ovigerous di Teluk Lasongko masing-masing terdistribusi pada
10, 12 dan 8 kelas ukuran dengan jumlah kelas ukuran dan frekuensinya bervariasi secara spatial-temporal dan berdasarkan tingkat kematangan gonad serta pada setiap warna telur rajungan betina ovigerous. Rajungan jantan dan betina secara spasialtemporal dan berdasarkan tingkat kematangan gonad didominasi oleh kelas ukuran lebar karapas dengan nilai tengah berkisar 94,85-124,85 mm. Frekuensi jumlah rajungan jantan dan betina yang matang gonad pada kisaran nilai tengah lebar karapas 84,85-124,85 $\mathrm{mm}$ semakin meningkat dengan meningkatnya lebar karapas. Rajungan betini ovigerous didominasi oleh kelas ukuran lebar karapas dengan nilai tengah 104,85-124,85 mm, dan frekuensi jumlah setiap warna telur rajungan betina ovigerous semakin meningkat dengan meningkatnya lebar karapas pada kisaran kelas ukuran tersebut. 


\section{Daftar Pustaka}

Adam, Jaya, I., dan Sondita, M.F. 2006. Model numerik diffusi populasi rajungan di perairan Selat Makassar. Jurnal IImu-IImu Perairan dan Perikanan Indonesia 13 (2): 83-88.

Ardika, P.U., Farajallah, A., Wardiatno, Y. 2015. First record of Hippa adactyla (Fabricius, 1787; Crustacea, Anomura, Hippidae) from Indonesian Waters. Tropical Life Sciences Research 26 (2): 105-110.

Batoy, C.B., Pilapil, B.C., Sarmago, J.F. 1988. Size composition, distribution, length-weight relationship and natural food of the blue crab, Portunus pelagicus (L.) in selected coastal waters in Leyte and vicinity, Philippines. Annals of Tropical Research 10(3): 127-142.

Chande, I., Mgaya, Y.D. 2003. The fishery of Portunus pelagicus and species diversity of portunid crabs along the coast of Dar es Salaam, Tanzania. Western Indian Ocean Journal Marine Science 2 (1) : 75-84.

De Lestang S., Hall, N.G., Potter, I.C. 2003. Reproductive biology of the blue swimmer crab (Portunus pelagicus, Decapoda: Portunidae) in five bodies of water on the West Coast of Australia. Fishery Bulletin 101: 745757.

Dhawan, R.M., Dwivedi, S.N. and Rajamanickam, G.V. 1976. Ecology of the blue crab Portunus pelagicus (Linnaeus) and its potential fishery in Zuari estuary. Indian Jornal Fisheries 23(1-2), 57-64.

DKP Sulawesi Tenggara. 2003. Penyusunan Detail Rencana Tata Ruang Pesisir dan Pulau-Pulau Kecil Kecamatan Lakudo, Kabupaten Buton Sulawesi Tenggara. Dinas Kelautan dan Perikanan Sulawesi Tenggara. Kendari

Edritanti, Q., Farajallah, A., Wardiatno, Y. 2016. Reproductive biology of ovigerous female Emerita emeritus (Crustacea, Decapoda) in Bengkulu coastal waters, Indonesia. Croatian Journal of Fisheries 74, 163-175.

Ernawati, T. 2013. Dinamika Populasi dan Pengkajian Stok Sumberdaya Rajungan (Portunus pelagicus) di
Perairan Kabupaten Pati dan Sekitarnya. Tesis. Sekolah Pascasarjana, Institut Pertanian Bogor. Bogor. 80 hal

Hamid, A. 2011. Kondisi kepiting rajungan di Teluk Lasongko Kabupaten Buton Provinsi Sulawesi Tenggara. Jurnal Mitra Bahari 5 (2) : 75-86.

Hamid, A., Wardiatno, Y. 2015. Population dynamics of the blue swimming crab (Portunus pelagicus Linnaeus, 1758) in Lasongko Bay, Central Buton, Indonesia. AACL Bioflux 8 (5) : 729739.

Hamid, A., Wardiatno, Y., Batu, D T. F. L., Riani, E. 2015a. Fekunditas dan Tingkat Kematangan Gonad Rajungan (Portunus pelagicus Linnaeus 1758) betina mengerami telur di Teluk Lasongko, Sulawesi Tenggara. Bawal

Hamid, A., Wardiatno, Y., Batu, D. T. F. L., Riani, E. 2015b. Changes in proximate and fatty acids of the eggs during embryo development in the blue swimming crab, Portunus pelagicus (Linnaeus 1758) at Lasongko bay, Southeast Sulawesi, Indonesia. Indian Journal of Science and Technology 8 (6) :501-509.

Hamid, A., Wardiatno, A., Batu, D.T.F.L., Riani, E. 2016. Distribution, body size, and eggs of ovigerous swimming crab (Portunus pelagicus Linnaeus 1758) at various habitats in Lasongko Bay, Central Buton, Indonesia. International Journal of Aquatic Biology 4 (2) : 115-124.

Ikhwanuddin, M., Azra, M., Siti-Aimuni, H., Abol-Munafi, A.B. 2012. Fecundity, embryonic and ovarian development of blue swimming crab, Portunus pelagicus (Linnaeus, 1758) in coastal water of Johor, Malaysia. Pakistan Journal of Biological Sciences 15: 720-728.

Johnson, D.D., Charles, G.A., Macbeth, W.G. 2010. Reproductive biology of Portunus pelagicus in a South-East Australian Estuary. Journal of Crustacean Biology 30 (2) : 200-205.

Johnston, D., Harris, D., Caputi, N, Thomson, A. 2011. Decline, contributing factors and future management strategy. Fisheries Reserach 109 (1) : 119-130. 
Johnston, D., Chandrapavan, A., Wise, B., Caputi, N. 2014. Recruitment and breeding stock levels in the PeelHarvey Estuary and status of the Mandurah to Bunbury Development Crab Fishery. Fisheries Research Report No. 258. Department of Fisheries, Western Australia. 148pp.

Kamrani, E., Sabili, A.N., Yahyav,i M. 2010. Stock assessment and reproductive biology of the blue Swimming crab, Portunus pelagicus in Bandar Abbas Coastal Waters, Northern Persian Gulf. Journal of the Persian Gulf (Marine Science) 1 (2) : 11-22.

Kunsook, C. 2011. Assessment of Stock and Movement Pattern for Sustainable Management of Blue Swimming Crab Portunus Pelagicus (Linnaeus, 1758): Case study in Kung Krabaen Bay, Chanthaburi Province, Thailand. PhD thesis. Chulalongkorn University. Bangkok. $166 p p$.

Kurnia, R., Boer, M., Zairion. 2014. Biologi populasi rajungan (Portunus pelagicus) dan karakteristik lingkungan habitat esensialnya sebagai upaya awal perlindungan di Lampung Timur. Jurnal Ilmu Pertanian Indonesia 19 (1) : 22-28.

Liu, Z., Wu, X., Wang, W., Yen, B., Cheng, Y. 2014. Ovariun development, size distribution and monthy variation of the female blue swimmer crab, Portunus pelagicus in Beibu Gulf, off South Cina. Scientia Marina 78 (2) : 257-268.

Mashar, A., Wardiatno, Y. 2013a. Aspek pertumbuhan undur-undur laut, Emerita emeritus dari pantai berpasir kabupaten Kebumen. Jurnal Biologi Tropis 13 (1) : 29-38.

Mashar, A. Wardiatno, Y. 2013b. Aspek pertumbuhan undur-undur laut, Hippa adactyla dari pantai berpasir kabupaten Kebumen. Jurnal Biologi Tropis 13 (2): 119-127.

Mashar, A., Wardiatno, Y., Boer, M., Butet, N.A., Farajallah, A. 2014. The diversity and abundance of sand crabs in south coast of Central Java. IImu Kelautan 19 (4) : 226-232.

Mashar, A., Wardiatno, Y., Boer, M., Butet, N.A., Farajallah, A., Ardika, P.U. 2015. First record of Albunea symmysta (Crustacea: Decapoda:
Albuneidae) from Sumatra and Java, Indonesia. AACL Bioflux 8 (4): 611615.

Muzammil, W., Wardiatno, Y., Butet, N.A. 2015. Rasio Panjang-Lebar Karapas, Pola Pertumbuhan, Faktor Kondisi, dan Faktor Kondisi Relatif Kepiting Pasir (Hippa adactyla) di Pantai Berpasir Cilacap dan Kebumen. Jurnal Ilmu Pertanian Indonesia 20 (1) : 78-84

Nugraheni, D. I., Fahrudin, A., Yonvitner. 2015. Variasi ukuran lebar karapas dan kelimpahan rajungan (Portunus pelagicus Linnaeus) di perairan Kabupaten Pati. Jurnal IImu dan Teknologi Kelautan Tropis 7 (2) : 493510.

Potter, I.C., de Lestang, S. 2000. Biology of the blue swimmer crab Portunus pelagicus in Leschenault Estuary and Koombana Bay, South-Western Australia. Journal of the Royal Society of Western Australia 83 : 443-458.

Potter, I.C., de Lestang, S., Melville-Smith, R. 2001. The Collection of Biological Data Required for Management of The Blue Swimmer Crab Fishery in The Central and Lower West Coasts of Australia. Centre for Fish and Fisheries Research, Murdoch University. Murdoch. 56p.

Razek, A.F.A., Taha, S.M., Ameran, A.A. 2006. Population biology of the edible crab Portunus pelagicus (Linnaeus) from Bardawil Lagoon, Northern Sinai, Egypt. Egyptian Journal of Aquatic Research 32 (1) : 401-418.

Santoso J., Hanifa, Y.N., Indariani, S., and Wardiatno, Y., Mashar, A. 2015. Nutritional values of the Indonesian mole crab, Emerita emeritus: are they affected by processing methods? AACL Bioflux 8(4), 579-587.

Sarong, M.A., Wardiatno, Y. 2013. Karakteristik habitat dan morfologi sarang undur-undur laut (Albunea) di zona littoral pesisir Leupung Kabupaten Aceh Besar. Jurnal EduBio Tropika 1 (1) : 1-60.

Sumpton, W.D., Potter, M.A., Smith, G.S. 1994. Reproduction and growth of the commercial sand crab, Portunus pelagicus (L.) in Moreton Bay, Queensland. Asian Fisheries Science $7: 103-113$. 
Sunarto. 2012. Karakteristik Bioekologi Rajungan (Portunus pelagicus) di Perairan Laut Kabupaten Brebes. Disertasi. Sekolah Pascasarjana, Institut Pertanian Bogor. Bogor. 175 hal

Sunarto, Soedharma, D., Riani, E., Martasuganda, S. 2010. Performa pertumbuhan dan reproduksi rajungan (Portunus pelagicus) di perairan pantai Kabupaten Brebes. OmniAkuatika $9(11): 75-82$.

Sukumaran, K.K., Neelakantan, B. 1998. Maturation process and reproductive cycle in two marine crabs, Portunus (Portunus) sanguinolentus (Herbst) and Portunus (Portunus) pelagicus (Linnaeus) along the Karnataka Coast. Indian Journal of Fisheries 45 (3) : 257-264.

Wardiatno, Y., Mashar, A. 2010 Biological information on the mantis shrimp, Harpiosquilla raphidea (Fabricius 1798) (Stomatopoda, Crustacea) in Indonesia with a highlight of its reproductive aspects. Journal of Tropical Biology and Conservation 7: 65-73.

Wardiatno, Y., Mashar, A. 2011 Population dynamics of the Indonesian mantis shrimp, Harpiosquilla raphidea (Fabricius 1798) (Crustacea: Stomatopoda) collected from a mud flat in Kuala Tungkal, Jambi Province, Sumatera Island. IImu Kelautan 16 (2): 111-118.

Wardiatno, Y., Mashar, A. 2013 Morphometric study of two Indonesian mantis shrimp (Harpiosquilla raphidea and Oratosquillina gravieri). Buletin PSP 21 (1): 19-30.

Wardiatno, Y., Santoso J., Mashar, A. 2012 Biochemical composition in two populations of the mantis shrimp, Harpiosquilla raphidea (Fabricius 1798) (Stomatopoda, Crustacea). IImu Kelautan 17(1): 49-58.

Wardiatno, Y., Nurjaya, I.W., Mashar, A. 2014. Karakteristik habitat undurundur laut (Famili Hippidae) di pantai berpasir, Kabupaten Cilacap. Jurnal Biologi Tropis 14 (1): 1-8.

Wardiatno, Y., Ardika, P.U., Farajallah, A., Mashar, A., Ismail. 2015a. The mole crab Hippa marmorata (Hombron et Jacquinot, 1846) (Crustacea Anomura Hippidae): a first record from
Indonesian waters. Biodiversity Journal 6 (2): 517-520.

Wardiatno, Y., Ardika, P.U., Farajallah, A., Butet, N.A., Mashar, A., Kamal, M.M., Renjaan, E.A., Sarong, M.A. 2015b. Biodiversity of Indonesian sand crabs (Crustacea, Anomura, Hippidae) and assessment of their phylogenetic relationships. AACL Bioflux 8 (2) : 224-235.

Wardiatno, Y., Hakim A.A., Mashar, A., Butet, N.A., Adrianto, L., Farajallah, A. 2016a. First record of Puerulus mesodontus Chan, Ma \& Chu, 2013 (Crustacea, Decapoda, Achelata, Palinuridae) from south of Java, Indonesia. Biodiversity Data Journal 4, e8069.

Wardiatno, Y., Hakim A.A., Mashar, A., Butet, N.A., Adrianto, L., Farajallah, A. $2016 \mathrm{~b}$. On the presence of the Andaman lobster, Metanephrops andamanicus (Wood-Mason, 1891) (Crustacea, Astacidea, Nephropidae) in Palabuhanratu bay (S-Java, Indonesia). Biodiversity Journal 7 (1): 17-20.

Wardiatno, Y., Hakim A.A., Mashar, A., Butet, N.A., Adrianto, L.. 2016c. Two Newly Recorded Species of the Lobster Family Scyllaridae (Thenus indicus and Scyllarides haanii) From South of Java, Indonesia. Hayati Journal of Biosciences (in press)

Wulandari, W.R., Boesono, H., Asriyanto. 2014. Analisis perbedaan kedalaman dan substrat dasar terhadap hasil tangkapan rajungan (swimming crab) dengan arad rajungan di perairan Wedung, Demak. Journal of Fisheries Resources Utilization Management and Technology 3 (4) : 85-93.

Zairion., Wardiatno,Y., Fahrudin, A., Boer, M. 2014a. Distribusi spasio-temporal populasi rajungan (Portunus pelagicus) betina mengerami telur di perairan pesisir Lampung Timur. Bawal 6 (2) : 95-102.

Zairion., Boer, M, Wardiatno,Y. Fahrudin, A. 2014b. Komposisi dan ukuran rajungan (Portunus pelagicus) yang tertangkap pada beberapa stratifikasi batimetri di Lampung Timur. Jurnal Penelitian Perikanan Indonesia 20 (4) : 199-206. 
Zairion., Wardiatno, Y., Fahrudin A., 2015. Sexual maturity, reproductive pattern and spawning female population of the blue swimming crab, Portunus pelagicus (Brachyura: Portunidae) in east Lampung coastal waters, Indonesia. Indian Journal of Science and Technology 8 (6) :596-607. 